\title{
The value of biomarkers in early diagnosis of anastomotic leak following colorectal tumor resection: a review of the literature between 2012 and 2017
}

\author{
Wei $\mathrm{Ge}^{1}$ and Gang Chen ${ }^{1}$ \\ ${ }^{1}$ Department of General Surgery, Nanjing Drum Tower Hospital, The Affiliated Hospital of Nanjing University Medical School, \\ Nanjing 210008, Jiangsu Province, P. R. China
}

Correspondence to: Gang Chen, email: 331812195@qq.com

Keywords: anastomotic leakage; early diagnosis; colorectal resection; biomarkers; inflammatory

Received: September 26, 2017

Accepted: October 27, 2017

Published: December 22, 2017

Copyright: Ge et al. This is an open-access article distributed under the terms of the Creative Commons Attribution License 3.0 (CC BY 3.0), which permits unrestricted use, distribution, and reproduction in any medium, provided the original author and source are credited.

\section{ABSTRACT}

\begin{abstract}
Anastomotic leakage $(\mathrm{AL})$ is one of the most serious complications of colorectal resection, causing sepsis, reducing overall in-hospital survival and increasing the risk of local and distant recurrences. So, early diagnosis of AL is very important. To improve the early diagnosis of AL following colorectal resection, a number of studies have investigated potential biomarkers to predict AL. In this review, we summarized the biomarkers, which had been shown to be useful in early diagnosis of AL. The results showed that c-reactive protein (CRP), procalcitonin (PCT), white blood cell count (WBC), cytokines, and so on were hot study biomarkers, which were proved to be reliable predictors of AL. Besides, drainage indexes such as microbiological study, potential of hydrogen ( $\mathrm{PH}$ ), carcinoembryonic antigen (CEA), and so on also helped to indicate early AL. Although there have been many studies on this field, rigorous homogeneous and prospective trials are demanded to explore ideal biomarkers to early diagnose $\mathrm{AL}$.
\end{abstract}

\section{INTRODUCTION}

At present, surgery is the main treatment of colorectal tumor. Enhanced recovery after surgery (ERAS) has gained momentum in the management of the colorectal cancer patient, which reduces morbidity and shortens the hospital stay [1]. Anastomotic leakage (AL) is one of the most serious complications of colorectal resection. Studies showed that AL occurs mainly around the 5th-7th postoperative day (POD) [2]. Early discharge according to ERAS carries a potential risk of developing $\mathrm{AL}$ when a patient is already out of the hospital. AL is a devastating complication, causing sepsis, reducing overall in-hospital survival and increasing the risk of local and distant recurrences [3,4]. So, early diagnosis of AL is very important.

To improve the early diagnosis of AL following colorectal resection, a number of studies have investigated potential biomarkers to predict AL. In this review, we summarized the biomarkers, which had been shown to be useful in early diagnosis of AL.
C-reactive protein

C-reactive protein (CRP) is a serum acute-phase reactant synthesized almost exclusively in the liver, released in response to stimulation by proinflammatory cytokines. Its production is part of a nonspecific acutephase response to most forms of tissue damage, infection, inflammation, malignant neoplasia and so on. The median concentration of CRP is $0.8 \mathrm{mg} / \mathrm{L}$ in adults, however, it may increase owing to acute -phase stimulus, stimulated by IL6 , a-TNF and IL- $1 \beta$ originating at the site of inflammation [5]. The half-life of CRP is very approximately 19h. All these characteristics make CRP a valuable biomarker for inflammatory response, early detection postoperative complication and so on [5]. Measuring CRP postoperatively to monitor the development of inflammatory and inflectional complication is considered standard care in many hospitals.

$\mathrm{AL}$ after colorectal resection may result in abdominal infection and also improve the CRP level, so elevated CRP may indirectly indicate AL theoretically. CRP has been 
reported in many studies to be raised significantly days before the diagnosis of AL. Almeida et al. performed a study to demonstrate the value of postoperative serum CRP in the identification of increased risk of AL after colorectal surgery. According to the result, the diagnosis of AL was mainly between the 4 th and 11 th postoperative day (POD, mean 7th POD). The cut-off value of $140 \mathrm{mg} / \mathrm{L}$ on POD3 maximized the sensitivity (78\%) and specificity (86\%) of serum CRP in assessing the risk of leakage [6]. Serum CRP has been evaluated in other 11 studies [7-17]. In general, the CRP level was raised significantly days before the diagnosis of AL. The reported cut-off values for CRP ranged from 130 to $245 \mathrm{mg} / 1$ for POD 3-5. Also, some results showed that CRP was a good negative predictive value for AL. The details were summarized in Table 1, Table 2, and Table 3. There are also studies to determine whether CRP in drain fluid can serve as screening tool for AL $[18,19]$. However, the results showed that examination CRP in drain fluid could not help to detect AL.

\section{Procalcitonin}

Procalcitonin (PCT) is the prohormone of calcitonin, synthesized by the parafollicular C-cells of the thyroid gland. PCT is consist of 116 amino acids, whose normal level in the circulation is very low $(<0.05 \mathrm{ng} / \mathrm{ml})$. Bacterial infections induce a generalized release of PCT from all differentiated cell types all over the body. Therefore, the level of PCT could rise significantly in the serum of patients. According to the literature, PCT would increase quickly after 2 to 3 hours following infection and rise to 700 $\mathrm{ng} / \mathrm{ml}$ in severe sepsis [20]. According to the characteristic of PCT, a value of which less than $0.5 \mathrm{ng} / \mathrm{mL}$ represents low risk of bacterial infection, while, a value of greater than $2 \mathrm{ng} / \mathrm{mL}$ shows a high risk of bacterial infection. PCT has an important characteristic that its level does not increase following inflammation of non-infectious origin, which is different from CRP. Besides, PCT has another interesting characteristic that its level increases before clinical signs present. All these characteristics make PCT as an ideal tool for early diagnosis of AL after colorectal surgery.

There are a series of studies showed that PCT help to early diagnose AL following colorectal surgery. Urszula er al. performed a study to assess the usefulness of the assessment of PCT in the diagnosis of AL. 157 patients underwent major elective colorectal surgery were involved in this study. They demonstrated the high accuracy of the PCT concentrations measured on day 1 following colorectal resection in the early prediction of AL. Low PCT value at this time point can be especially helpful in excluding AL from the differential diagnosis [21]. Another study by Marek showed that PCT measurement on POD 3 following colorectal cancer resection can positively identify patients at low risk of anastomotic leakage. The cut-off for PCT on POD 3 was $3.83 \mathrm{ng} / \mathrm{ml}$, with sensitivity of $75 \%$ and specificity of $100 \%$ for AL [12]. A study performed in
Spain also concluded that PCT is reliable predictor of major anastomotic leak after colorectal resection. Raised PCT serum concentration on postoperative days 3 to 5 renders necessary a careful evaluation of the patient before discharge [9]. Similar conclusions had been got in other researches [7, $10,14,18]$. There are also studies to determine whether PCT in drain fluid can serve as screening tool for AL [19]. Unfortunately, the results showed that examination of PCT in drain fluid could not help to detect AL.

\section{White blood cell count}

White blood cell count (WBC) plays an important role in elimination of microorganisms and wound healing. If inflammation is present in the body due to any reason (infection, trauma or tumoral differentiation), WBC presence or increases at inflammation site are common. So the level of WBC could reflect the degree of inflammation. $\mathrm{AL}$ would cause inflammatory reaction as the intestinal contents flowed into the abdominal cavity. Therefore, WBC may act as an indicator to predict AL. According to this deduction, a series of studies had been tried to verify this hypothesis. Torben et al. performed a study to determine whether the WBC has a role as early predictor of postoperative septic complications including AL in patients operated laparoscopically in a fast-track regimen. The result showed that the best cut-off value for WBC as a predictor of septic complications was observed on POD2, where WBC > $12^{*} 10^{\wedge} 9$ had a sensitivity of $90 \%$ and a specificity of $62 \%$. So they concluded that WBC maybe a weak diagnostic marker in prediction of post-operative septic complications, including AL [8]. Stephen et al. also showed that WBC maybe a potential marker of AL. following colorectal surgery [16]. However, some other studies got the opposite conclusion. There was another study aimed to demonstrate the value of WBC in the identification of increased risk of AL after colorectal surgery. Comparison of postoperative serum WBC values did not show any significant differences between AL group and non-AL group until the POD6 [6]. Another two studied got the similar conclusion that WBC was not an ideal biomarker for predicting AL $[10,14]$. Therefore, further studies should be performed to explore the value of WBC in the early diagnosis of AL.

\section{Cytokines}

Some cytokines such as IL-6, IL-8, IL-10 and $\mathrm{TNFa}$ are produced in response to various inflammation mediators. In the group of patients with tumors and inflammatory disease of bowel, the levels of these cytokines may be related to underlying disease to a great extent. Base on these characteristics, cytokines maybe the potential biomarker for AL following colorectal surgery. Serum and peritoneal cytokines have been tried to predict AL. Kostan et al. performed a study to verify whether serum IL- 6 could be a hallmark of AL. The result showed 
Table 1: The general characteristics of the studies included in this review investigating potential biomarkers to predict AL

\begin{tabular}{lccccc}
\hline First auther, year, reference & Study design & Open approach & Operation for cancer & Num & AL rate \\
\hline Almeida, 2012, [6] & Prospective & $82 \%$ & $74.60 \%$ & 173 & $13.90 \%$ \\
Lagoutte, 2012, [7] & Prospective & $65 \%$ & $52 \%$ & 100 & $13 \%$ \\
Torben, 2012, [8] & Retrospective & $0 \%$ & - & 129 & $18 \%$ \\
Alvaro, 2013, [9] & Prospective & $79 \%$ & $73.20 \%$ & 205 & $8.30 \%$ \\
Giaccaglia, 2014, [10] & Prospective & $89.90 \%$ & $93.90 \%$ & 99 & $7.10 \%$ \\
Kostan, 2014, [11] & Prospective & $48 \%$ & $100 \%$ & 84 & $10 \%$ \\
Marek, 2015, [12] & Prospective & $47.30 \%$ & $100 \%$ & 55 & $9.10 \%$ \\
Waterland, 2016, [13] & Prospective & $36 \%$ & - & 727 & $7.90 \%$ \\
Valentina, 2016, [14] & Prospective & $25 \%$ & $100 \%$ & 504 & $5.60 \%$ \\
Michal, 2017, [15] & Prospective & - & $100 \%$ & 724 & $4.60 \%$ \\
Stephen, 2017, [16] & Prospective & - & $100 \%$ & 197 & $5.60 \%$ \\
Burke, 2017, [17] & Prospective & $77.70 \%$ & $100 \%$ & 211 & $12.80 \%$ \\
Ismail, 2017, [18] & Prospective & $92 \%$ & $100 \%$ & 50 & $14 \%$ \\
Komen, 2014, [19] & Prospective & - & - & 243 & $8 \%$ \\
Urszula, 2016, [21] & Prospective & $21.70 \%$ & $60.50 \%$ & 157 & $10.30 \%$ \\
Tarik, 2016, [22] & Prospective & - & $64.60 \%$ & 206 & $8.30 \%$ \\
Elyamani, 2011, [23] & Prospective & $100 \%$ & $100 \%$ & 56 & $14.30 \%$ \\
Käser, 2014, [25] & Retrospective & - & - & 1106 & $7.30 \%$ \\
Liu, 2013, [26] & Prospective & $97.50 \%$ & $63.80 \%$ & 753 & $7.60 \%$ \\
Liron, 2016, [27] & Prospective & $30.50 \%$ & & 105 & $9.50 \%$ \\
\hline
\end{tabular}

that IL-6 levels were not different between patients with and without AL at any time point. So, IL-6 was not a prefer biomarker for AL [11]. Similar conclusion had been got by Urszula. Their results showed that patients who developed AL had higher concentrations of IL-6 on POD1, but the difference was not significant. So they thought that IL-6 is not a good early marker for developing AL [21]. There were also studies to confirm the value of peritoneal cytokines in detecting AL. Accumulating evidence suggests that peritoneal cytokine concentrations may predict AL after colorectal surgery. Tarik et al. showed that concentration levels of peritoneal IL- 6 and IL-10 on day 1 after colorectal surgery were predictive of AL (area under receiver operating characteristic curve, 0.72 and 0.74 ; $p=0.006$ and 0.004 ). These results suggest that peritoneal levels of IL-6 and IL-10 are predictive of AL [22, 23]. Whereas, another study showed that peritoneal IL-6 was not a good index to predict AL and increasing levels of TNFa is predictive [18]. So, further studies should be made to explore to the value of cytokines in the use of early diagnosis of AL.

\section{Microbiological study in drainage}

When AL attacks in colorectal surgery, intestinal bacteria may flow into the abdominal cavity. Ruiter et al. reported that the composition of the microbial flora present in the abdominal fluid of patients critically ill with abdominal sepsis varies depending on location of the perforation [24]. In lower gastrointestinal perforation, the most frequently isolated aerobic organisms were E. coli, Klebsiella, and Pseudomonas species. The predominant anaerobes were Bacteroides [24]. So that testing the concentration of these concentration bacteria in drainage may in turn predict AL. Based on this assumption, Elyamani et al. performed a bacteriological study to predict AL. Their result showed that Escherichia coli, Klebsiella, Pseudomonas species, and bacteriod micro-organism were significantly more in AL group in first, third, fifth days postoperatively. They concluded that intraperitoneal bacterial colonization might be an additional diagnostic tool that can support the decision making of surgeons for early detection of AL in colorectal surgery [23]. Another study by Ismail et al. got similar conclusion that bacterial proliferation in drain fluid is predictive for assessing of AL [18].

\section{Some uncommon markers in serum}

There are some uncommon markers in serum had also been tried to diagnose AL early. These markers are mainly divided into inflammatory markers and 
Table 2: The sample source, testing biomarkers and testing time of the studies included in this review

\begin{tabular}{|c|c|c|c|}
\hline First auther, year, reference & Sample source & Biomarkers included & Time interval \\
\hline Almeida, 2012, [6] & Serum & CRP, WBC & Daily (between POD1 and POD9) \\
\hline Lagoutte, 2012, [7] & Serum & CRP, PCT & Daily (between POD1 and POD4) \\
\hline Torben, 2012, [8] & Serum & CRP, WBC & Daily until discharge \\
\hline Alvaro, 2013, [9] & Serum & PCT, CRP & Daily (between POD1 and POD5) \\
\hline Giaccaglia, 2014, [10] & Serum & WBC, CRP, PCT & POD1, POD3 and POD5 \\
\hline Kostan, 2014, [11] & Serum & CRP, Calprotectin, IL-6 & Daily during hospital \\
\hline Marek, 2015, [12] & Serum & CRP, PCT & POD 1 and POD 3 \\
\hline Waterland, 2016, [13] & Serum & CRP & Daily (between POD1 and POD7) \\
\hline Valentina, 2016, [14] & Serum & PCT, CRP, WBC & POD3 and POD5 \\
\hline Michal, 2017, [15] & Serum & CRP, NLR & POD0 and POD4 \\
\hline Stephen, 2017, [16] & Serum & CRP, PCT, WCC, GGT & Daily (between POD1 and POD5) \\
\hline Burke, 2017, [17] & Serum & CRP & Daily (between POD1 and POD7) \\
\hline Ismail, 2017, [18] & $\begin{array}{l}\text { Drainage and } \\
\text { serum }\end{array}$ & $\begin{array}{l}\text { Serum (CRP, PCT); Drainage } \\
\text { (bacterial proliferation, IL-6, } \\
\text { TNFa) }\end{array}$ & $\begin{array}{l}\text { Serum (POD1 and POD3), } \\
\text { Drainage (POD1, POD3, and POD5) }\end{array}$ \\
\hline Komen, 2014, [19] & Drainage & CRP, LBP, PCT & Daily (between POD1 and POD5) \\
\hline Urszula, 2016, [21] & Serum & PCT, IL-6 & POD0 and POD1 \\
\hline Tarik, 2016, [22] & $\begin{array}{l}\text { Drainage and } \\
\text { serum }\end{array}$ & IL-6, IL-8, IL-10, and TNFa & POD1 \\
\hline Elyamani, 2011, [23] & Drainage & $\begin{array}{l}\text { Microbiological study, IL-6, } \\
\text { IL-10, TNF }\end{array}$ & POD 1, POD 3, and POD5 \\
\hline Käser, 2014, [25] & Serum & Sodium level, WBC & As close as possible to POD5 \\
\hline Liu, 2013, [26] & Drainage & $\mathrm{PH}$ & Daily (between POD1 and POD12) \\
\hline Liron, 2016, [27] & Drainage & CEA & POD1, POD2, and POD3 \\
\hline
\end{tabular}

CRP: C-reactive protein; WBC: White blood cell count, PCT: Procalcitonin, NLR: Neutrophil to lymphocyte ratio, LBP: Lipopolysaccharide-binding protein, PH: Potential of hydrogen, CEA: Carcinoembryonic antigen, POD: Postoperative day.

intestinal damage markers. Inflammatory markers such as calprotectin, gamma-glutamyl transferase, neutrophil to lymphocyte ratio (NLR) had been studied. Kostan et al. tried to test calprotectin as suitable biomarker for AL. They found that calprotectin had the best diagnostic accuracy to detect AL postoperatively. Highest diagnostic accuracy was obtained when CRP and calprotectin were combined at POD3, yielding sensitivity of $100 \%$, specificity of $89 \%$, positive likelihood ratio $=9.09$, and negative likelihood ratio $=0.00$ [11]. So calprotectin may be a potential biomarker for detecting AL worth further study. Gamma-glutamyl transferase was assessed Stephen et al. for predictive utility in diagnosing AL. They got the result that there was no association of gamma-glutamyl transferase with AL [16]. NLR is another hot inflammation marker and it is also been assessed the prognostic value in the development of AL. The accuracy of NLR in the detection of AL using area under curve was 0.68 with the optimal cut-off value of 6.5 , sensitivity $69 \%$, specificity $78 \%$, PPV 49\% and NPV 88\% [15]. According to this result, NLR on POD4 possesses the ability to predict the development of AL.

Markers of gut damage might be suitable for detecting AL early, as these are hallmarks of AL. Kostan et al. tested intestinal damage markers such as intestinal fatty acid binding protein, liver fatty acid binding protein, and ileal bile acid binding protein to predict AL. They found that preoperative intestinal fatty acid binding protein levels predicted anastomotic leakage at a cutoff level of $882 \mathrm{pg} /$ $\mathrm{mL}$ with sensitivity of $50 \%$, specificity of $100 \%$, positive likelihood ratio $=$ infinite and negative likelihood ratio $=0.50$ [11]. So that preoperative intestinal fatty acid binding protein measurement can be used for AL risk assessment. Besides, some markers of internal environment were used to act as biomarker of AL. There was a study to define the significance of hyponatremia as a marker of AL after colorectal surgery. They found that hyponatremia could be a specific and relevant marker of AL after colorectal surgery with a specificity of $93 \%$ and a sensitivity of $23 \%$ [25]. However, such studies are few and need to be confirmed further. 
Table 3: The effective biomarkers, and diagnostic efficiency of the studies included in this review

\begin{tabular}{|c|c|c|}
\hline $\begin{array}{l}\text { First auther, year, } \\
\text { reference }\end{array}$ & Effective biomarkers & Diagnostic efficiency \\
\hline Almeida, 2012, [6] & CRP (POD3, cutoff value: $140 \mathrm{mg} / \mathrm{L}$ ) & Sensitivity $78 \%$, specilficity $86 \%$ \\
\hline Lagoutte, 2012, [7] & $\begin{array}{l}\text { CRP (POD3, cutoff value: } 13.0 \mathrm{mg} / \mathrm{dL} \text { ), } \\
\text { PCT(POD3, cutoff value: } 0.068 \mathrm{mg} / \mathrm{dL} \text { ) }\end{array}$ & $\begin{array}{l}\text { CRP (sensitivity } 70 \% \text {, specilficity } 70 \% \text { ), } \\
\text { PCT (sensitivity } 70 \% \text {, specilficity } 70 \% \text { ) }\end{array}$ \\
\hline Torben, 2012, [8] & $\begin{array}{l}\text { CRP (POD3, cutoff value: } 200 \mathrm{mg} / \mathrm{L}) \\
\left.\text { WBC (POD2, cutoff value: } 12^{*} 10^{\wedge} 9\right)\end{array}$ & $\begin{array}{l}\text { CRP (sensitivity } 68 \% \text {, specilficity } 74 \% \text { ); } \\
\text { WBC (sensitivity } 90 \% \text {, specilficity } 62 \% \text { ) }\end{array}$ \\
\hline alvaro, 2013, [9] & PCT (POD5, cutoff value: $0.31 \mathrm{ng} / \mathrm{ml}$ ) & Sensitivity $72 \%$, specilficity $100 \%$ \\
\hline Giaccaglia, 2014, [10] & PCT (POD3 and POD5) & $\begin{array}{l}\text { Negative predictive value } \\
\text { (96.7\% and } 96.7 \% \text { respectively) }\end{array}$ \\
\hline Kostan, 2014, [11] & CRP: POD4, cutoff value: $99 \mathrm{mg} / \mathrm{L}$, & Sensitivity $100 \%$, specilficity $64 \%$ \\
\hline Marek, 2015, [12] & $\begin{array}{l}\text { CRP (POD3, cutoff value: } 245.64 \mathrm{mg} / \mathrm{l}) \\
\text { PCT (POD3, cutoff value:3.83 ng/ml) }\end{array}$ & $\begin{array}{l}\text { CRP (sensitivity } 100 \% \text {, specilficity } 98 \% \text { ), } \\
\text { PCT (sensitivity } 75 \% \text {, specilficity } 100 \% \text { ) }\end{array}$ \\
\hline Waterland, 2016, [13] & $\begin{array}{l}\text { CRP (POD3 and POD } 4 \text { with cut-off value of } \\
209 \text { and } 123.5 \mathrm{mg} / \mathrm{ml} \text { in laparotomy); CRP } \\
\text { (POD2 with cut-off value of } 146.5 \mathrm{mg} / \mathrm{ml} \text { in } \\
\text { laparoscopy) }\end{array}$ & $\begin{array}{l}\text { CRP (sensitivity } 80 \% \text {, specilficity } 80 \% \text { on } \\
\text { POD3 and sensitivity } 94 \% \text {, specilficity } 60 \% \text { on } \\
\text { POD4 in laparotomy); CRP (sensitivity } 75 \% \text {, } \\
\text { specilficity } 70 \% \text { on POD2 in laparoscopy) }\end{array}$ \\
\hline Valentina, 2016, [14] & $\mathrm{PCT}, \mathrm{CRP}$ & Negative predictive value \\
\hline Michal, 2017, [15] & $\begin{array}{l}\text { CRP (POD4, cutoff value: } 180 \mathrm{mg} / \mathrm{L} \text { ), } \\
\text { NLR (POD4, cutoff value:6.5) }\end{array}$ & $\begin{array}{l}\text { CRP (sensitivity } 75 \% \text {, specilficity } 91 \% \text { ), } \\
\text { NLR (sensitivity } 69 \% \text {, specilficity } 78 \% \text { ) }\end{array}$ \\
\hline Stephen, 2017, [16] & CRP, cutoff value: 53 units & $\begin{array}{l}\text { Sensitivity } 90.9 \% \text {, specilficity } 95.7 \% \text {. } \\
\text { a daily rise of around } 50 \text { units being most } \\
\text { predictive }\end{array}$ \\
\hline Burke, 2017, [17] & CRP (POD5, cutoff value:132 mg/l), & CRP (sensitivity 70\%, specilficity $76.6 \%$ ), \\
\hline Ismail, 2017, [18] & $\begin{array}{l}\text { Serum CRP and PCT (POD3), Drain } \\
\text { TNF-a and bacterial proliferation (POD5) }\end{array}$ & \\
\hline Komen, 2014, [19] & LBP & $\begin{array}{l}\text { An increase in the average initial value at } \\
\text { the first postoperative day with } 1 \text { standard } \\
\text { deviation increased the risk of leakage by } \\
1.6 \text { times. }\end{array}$ \\
\hline Urszula, 2016, [21] & PCT (POD1, cutoff value: $1.09 \mathrm{ng} / \mathrm{mL}$ ) & Sensitivity $87 \%$, specilficity $87 \%$ \\
\hline Tarik, 2016, [22] & $\begin{array}{l}\text { Peritoneal IL-6 (POD1, cutoff value:3091 pg/ml); } \\
\text { peritoneal IL-10 (POD1, cutoff value:504 pg/ml) }\end{array}$ & $\begin{array}{l}\text { Peritoneal IL-6 (sensitivity } 86 \% \text {, } \\
\text { specilficity } 52 \% \text { ), peritoneal IL-10 } \\
\text { (sensitivity } 86 \% \text {, specilficity } 62 \% \text { ) }\end{array}$ \\
\hline Elyamani, 2011, [23] & $\begin{array}{l}\text { Cytokines (IL-6, IL-10, TNF), microbiological } \\
\text { study (Escherichia coli, Klebsiella, } \\
\text { Pseudomonas species, and bacteriod micro- } \\
\text { organism) }\end{array}$ & \\
\hline Käser, 2014, [25] & Hyponatremia & Sensitivity $23 \%$, specilficity $93 \%$ \\
\hline Liu, 2013, [26] & PH: POD3, cutoff value: 6.978 & Sensitivity $98.7 \%$, specilficity $94.7 \%$ \\
\hline Liron, 2016, [27] & CEA $(1000 \mathrm{ng} / \mathrm{mL})$ & \\
\hline
\end{tabular}

\section{Some uncommon markers in drainage}

Testing peritoneal biomarkers to detect AL seems to be more direct and accurate. So expect for CRP, PCT, WBC, and microbiological study, there were some other peritoneal markers had been tried to predict AL following colorectal surgery. Liu et al. try to demonstrate the value of potential of hydrogen $(\mathrm{PH})$ of pelvic drainage in the identification of increased risk of AL after anterior resection for rectal cancer with a double stapling technique. They got positive result and concluded that an early and persistent decline of $\mathrm{PH}$ value of pelvic 
drainage fluid after rectal surgery with anastomosis, is a marker of AL. A cut-off value of 6.978 determined at $25^{\circ} \mathrm{C}$ on POD3 maximizes the sensitivity and specificity [26]. Evidences showed that carcinoembryonic antigen (CEA) elevation were associated with the inflammation process that accompanies AL [19]. So the idea that measuring CEA of drain as an indicator of AL was put forward. According to this idea, Liron et al. evaluated CEA levels in abdominal drains after colorectal resection to assess its potential as an early marker to predict AL. The result showed that early anastomotic dehiscence was associated with a significant elevation of CEA in drain fluids. So they concluded that significant elevation of CEA levels in abdominal drains in the early postoperative period may indicate early anastomotic dehiscence [27]. Besides, there were also researchers aimed to determine if lipopolysaccharide-binding protein (LBP) can serve as screening tool for colorectal AL. They got that increased concentrations of LBP in drain fluid are significantly associated to a higher chance of AL and could contribute in a future prognostic model for AL [19]. Peritoneal biomarkers for detecting AL is very promising and worth further attempt.

\section{Prospect}

With the advance of ERAS, patients underwent colorectal resection discharged before AL appears. So, early detection of AL is important and significant. This paper above had summarized the studies about biomarkers for early diagnosing of AL. Some results were valuable and got some biomarkers to detect AL such as CRP, CPT, Microbiological study and so on. However, owing to the effect of sample size and research design, these studies did not get the unified conclusion. Besides, according the results, these indexes are more suitable for negatively predicting AL. So new ideal biomarkers for early diagnosing AL are need to be discovered. In my opinion, biomarkers in drain may be potential to detect AL early and accurately. As when AL happens, exception occurs firstly in anastomoses, so testing the drain around the anastomoses may get the sign early. Further, when AL happens, the intestinal juice may fly into the abdominal cavity. The intestinal juice contains a lot of bacteria and is acidic, so testing the $\mathrm{PH}$ of drain the marking microbiological study may contribute to detecting AL. Although there have been studies on this field, these studies were so few and the simple sizes were not large. Rigorous homogeneous and prospective trials are demanded to further confirm the role of drain in the early diagnosis of AL following colorectal resection.

\section{CONFLICTS OF INTEREST} interests.

\section{REFERENCES}

1. Kisialeuski M, Pedziwiatr M, Matlok M, Major P, Migaczewski M, Kolodziej D, Zub-Pokrowiecka A, Pisarska M, Budzynski P, Budzynski A. Enhanced recovery after colorectal surgery in elderly patients. Wideochir Inne Tech Maloinwazyjne. 2015; 10:30-36.

2. Blumetti J, Chaudhry V, Cintron JR, Park JJ, Marecik S, Harrison JL, Prasad LM, Abcarian H. Management of anastomotic leak: lessons learned from a large colon and rectal surgery training program. World J Surg. 2014; 38:985-991.

3. Midura EF, Hanseman D, Davis BR, Atkinson SJ, Abbott DE, Shah SA, Paquette IM. Risk factors and consequences of anastomotic leak after colectomy: a national analysis. Dis Colon Rectum. 2015; 58:333-338.

4. Nachiappan S, Faiz O. Anastomotic Leak Increases Distant Recurrence and Long-term Mortality After Curative Resection for Colonic Cancer. Ann Surg. 2015; 262:e111.

5. Welsch T, Muller SA, Ulrich A, Kischlat A, Hinz U, Kienle P, Buchler MW, Schmidt J, Schmied BM. C-reactive protein as early predictor for infectious postoperative complications in rectal surgery. Int J Colorectal Dis. 2007; 22:1499-1507.

6. Almeida AB, Faria G, Moreira H, Pinto-de-Sousa J, Correia-da-Silva P, Maia JC. Elevated serum C-reactive protein as a predictive factor for anastomotic leakage in colorectal surgery. Int J Surg. 2012; 10:87-91.

7. Lagoutte N, Facy O, Ravoire A, Chalumeau C, Jonval L, Rat $\mathrm{P}$, Ortega-Deballon P. C-reactive protein and procalcitonin for the early detection of anastomotic leakage after elective colorectal surgery: pilot study in 100 patients. J Visc Surg. 2012; 149:e345-349.

8. Pedersen T, Roikjaer O, Jess P. Increased levels of C-reactive protein and leukocyte count are poor predictors of anastomotic leakage following laparoscopic colorectal resection. Dan Med J. 2012; 59:A4552.

9. Garcia-Granero A, Frasson M, Flor-Lorente B, Blanco F, Puga R, Carratala A, Garcia-Granero E. Procalcitonin and $\mathrm{C}$-reactive protein as early predictors of anastomotic leak in colorectal surgery: a prospective observational study. Dis Colon Rectum. 2013; 56:475-483.

10. Giaccaglia V, Salvi PF, Cunsolo GV, Sparagna A, Antonelli MS, Nigri G, Balducci G, Ziparo V. Procalcitonin, as an early biomarker of colorectal anastomotic leak, facilitates enhanced recovery after surgery. J Crit Care. 2014; 29:528-532.

11. Reisinger KW, Poeze M, Hulsewe KW, van Acker BA, van Bijnen AA, Hoofwijk AG, Stoot JH, Derikx JP. Accurate prediction of anastomotic leakage after colorectal surgery using plasma markers for intestinal damage and inflammation. J Am Coll Surg. 2014; 219:744-751.

12. Zawadzki M, Czarnecki R, Rzaca M, Obuszko Z, Velchuru VR, Witkiewicz W. C-reactive protein and procalcitonin predict anastomotic leaks following colorectal cancer 
resections - a prospective study. Wideochir Inne Tech Maloinwazyjne. 2016; 10:567-573.

13. Waterland P, Ng J, Jones A, Broadley G, Nicol D, Patel $\mathrm{H}$, Pandey S. Using CRP to predict anastomotic leakage after open and laparoscopic colorectal surgery: is there a difference? Int J Colorectal Dis. 2016; 31:861-868.

14. Giaccaglia V, Salvi PF, Antonelli MS, Nigri G, Pirozzi F, Casagranda B, Giacca M, Corcione F, de Manzini N, Balducci G, Ramacciato G. Procalcitonin Reveals Early Dehiscence in Colorectal Surgery: The PREDICS Study. Ann Surg. 2016; 263:967-972.

15. Mik M, Dziki L, Berut M, Trzcinski R, Dziki A. Neutrophil to Lymphocyte Ratio and C-Reactive Protein as Two Predictive Tools of Anastomotic Leak in Colorectal Cancer Open Surgery? Dig Surg. 2018; 35:77-84.

16. Smith SR, Pockney P, Holmes R, Doig F, Attia J, Holliday E, Carroll R, Draganic B. Biomarkers and anastomotic leakage in colorectal surgery: C-reactive protein trajectory is the gold standard. ANZ J Surg. 2017.

17. Reynolds IS, Boland MR, Reilly F, Deasy A, Majeed MH, Deasy J, Burke JP, McNamara DA. C-reactive protein as a predictor of anastomotic leak in the first week after anterior resection for rectal cancer. Colorectal Dis. 2017; 19:812-818.

18. Bilgin IA, Hatipoglu E, Aghayeva A, Arikan AE, Incir S, Mamal Torun M, Dirican A, Erguney S. Predicting Value of Serum Procalcitonin, C-Reactive Protein, Drain Fluid Culture, Drain Fluid Interleukin-6, and Tumor Necrosis Factor-alpha Levels in Anastomotic Leakage after Rectal Resection. Surg Infect (Larchmt). 2017; 18:350-356.

19. Komen N, Slieker J, Willemsen P, Mannaerts G, Pattyn P, Karsten T, de Wilt H, van der Harst E, de Rijke YB, Murawska M, Jeekel J, Lange JF and APPEAL Study Group. Acute phase proteins in drain fluid: a new screening tool for colorectal anastomotic leakage? The APPEAL study: analysis of parameters predictive for evident anastomotic leakage. Am J Surg. 2014; 208:317-323.
20. Maruna P, Nedelnikova K, Gurlich R. Physiology and genetics of procalcitonin. Physiol Res. 2000; 49 Suppl $1:$ S57-61.

21. Zielinska-Borkowska U, Dib N, Tarnowski W, Skirecki T. Monitoring of procalcitonin but not interleukin-6 is useful for the early prediction of anastomotic leakage after colorectal surgery. Clin Chem Lab Med. 2017; 55:1053-1059.

22. Sammour T, Singh PP, Zargar-Shoshtari K, Su'a B, Hill AG. Peritoneal Cytokine Levels Can Predict Anastomotic Leak on the First Postoperative Day. Dis Colon Rectum. 2016; 59:551-556.

23. Fouda E, El Nakeeb A, Magdy A, Hammad EA, Othman G, Farid M. Early detection of anastomotic leakage after elective low anterior resection. J Gastrointest Surg. 2011; 15:137-144.

24. de Ruiter J, Weel J, Manusama E, Kingma WP, van der Voort PH. The epidemiology of intra-abdominal flora in critically ill patients with secondary and tertiary abdominal sepsis. Infection. 2009; 37:522-527.

25. Kaser SA, Nitsche U, Maak M, Michalski CW, Spath C, Muller TC, Maurer CA, Janssen KP, Kleeff J, Friess H, Bader FG. Could hyponatremia be a marker of anastomotic leakage after colorectal surgery? A single center analysis of 1,106 patients over 5 years. Langenbecks Arch Surg. 2014; 399:783-788.

26. Yang L, Huang XE, Xu L, Zhou X, Zhou JN, Yu DS, Li DZ, Guan X. Acidic pelvic drainage as a predictive factor for anastomotic leakage after surgery for patients with rectal cancer. Asian Pac J Cancer Prev. 2013; 14:5441-5447.

27. Berkovich L, Hermann N, Ghinea R, Avital S. Significant elevation of carcinoembryonic antigen levels in abdominal drains after colorectal surgery may indicate early anastomotic dehiscence. Am J Surg. 2016; 212:545-547. 